\title{
A sejten kívüli szabad DNS felszabadulásának és degradációjának in vivo elemzése
}

\author{
Barták Barbara Kinga $^{1}$ - Nagy Zsófia Brigitta ${ }^{1}$ \\ Spisák Sándor dr. ${ }^{3}$. Tulassay Zsolt dr. ${ }^{1,4}$. Dank Magdolna dr. $^{2}$ \\ Igaz Péter dr. ${ }^{1,4}$. Molnár Béla dr. ${ }^{1,4}$ \\ Semmelweis Egyetem, Általános Orvostudományi Kar, \\ ${ }^{1}$ II. Belgyógyászati Klinika, Molekuláris Gasztroenterológiai Laboratórium, ${ }^{2}$ Onkológiai Központ, Budapest \\ ${ }^{3}$ Department of Medical Oncology, Dana-Farber Cancer Institute, Boston, Massachusetts, USA \\ ${ }^{4}$ Magyar Tudományos Akadémia, Molekuláris Medicina Kutatócsoport, Budapest
}

\begin{abstract}
Bevezetés: A sejten kívüli szabad DNS-t már az 1940-es években kimutatták. Eredetérôl több elmélet is létezik: lehetséges folyamat a tumoros sejtekből, valamint ezzel párhuzamosan az egészséges sejtekből történő felszabadulás is. Célkitüzés: Munkánk célja a szabad DNS felszabadulási ütemének vizsgálata volt SHO-egér/HT-29 humán colorectalis adenocarcinoma sejtvonal xenograftmodellben, valamint célul tűztük ki egészséges és C38 tumorral oltott C57BL/6-os egerek véráramába juttatott mesterségesen fölszaporított metilált és nem metilált DNS-szakaszok lebomlásának nyomon követését.

Módszer: SHO-egerekre HT-29 sejteket oltottunk subcutan, majd vért vettünk 8 héten keresztül. A plazma szeparálása után DNS-t izoláltunk, majd mitokondriális és genomiális RT-PCR-próbákkal megállapítottuk a humán/egér DNS-arányt. A szabad DNS lebomlásának vizsgálatához egészséges és C38 tumorsejttel oltott C57BL/6-os állatok vérébe 3000 bázispár (bp) méretü in vitro metilált és nem metilált DNS-fragmentumot juttattunk. Az amplikonok degradációját 19 valós idejű PCR-próbával mértük, a bomlás ütemére a relatív amplikonkoncentrációk alapján következtettünk.

Eredmények: A tumorból származó humán DNS mennyisége a 2. hétig a kimutathatósági határ alatt volt, majd a 3. héttól folyamatos emelkedést tapasztaltunk, amely a 8 . hétre 18,26\%-ot ért el. A véráramba juttatott DNS-szakaszok lebomlásának sebességében különbséget mutattunk ki a nem metilált és a metilált fragmentumok között. Az egészséges állatokban a nem metilált DNS 6 óra után eltűnt a vérplazmából, míg a metilált fragmentum szakaszai 24 óra múlva is kimutathatók voltak. Tumoros állatokban a degradáció mértéke lelassult, és mindkét forma kimutathatóvá vált 24 óra elteltével.

Következtetés: A szabad DNS szerepének és hatásmechanizmusának vizsgálatát egyre nagyobb érdeklődés övezi. Munkánk segítséget nyújthat a DNS felszabadulásának és degradációjának pontosabb megismeréséhez.
\end{abstract}

Orv Hetil. 2018; 159(6): 223-233.

Kulcsszavak: szabad DNS, DNáz-aktivitás, xenograftmodell, plazma

\section{In vivo analysis of circulating cell-free DNA release and degradation}

Introduction: Cell-free DNA (cfDNA) was first detected in human plasma in the 1940s, but the knowledge on its regulation and rate of release is incomplete. CfDNA can originate from both normal and tumour cells.

Aim: Our aims were to investigate the rate of cfDNA's release in SHO mice/HT-29 colorectal adenocarcinoma cell line xenograft model and to define the decay of methylated and non-methylated DNA fragments in C57BL/6 bloodstream.

Method: SHO mice were xenografted with human HT-29 cells, than blood samples were collected over 2 months. CfDNA was isolated, then quantified by real-time PCR with highly specific genomic and mitochondrial human and mouse primer sets. This method permitted to define the ratio of human/mouse DNA. To assess the degradation rate of cfDNA, 3000 bp sized methylated and non-methylated DNA fragments were injected into healthy and C38 tumour-cell vaccinated C57BL/6 mice's bloodstream. The decay of amplicons was measured with 19 PCR assays.

Results: The amount of human DNA until the 2 nd week was below the limit of detection. From the third week, a continuous growth was experienced, which reached $18.26 \%$ by the 8 th week. Moreover, it was found that in healthy 
animals the non-methylated DNA disappears from the plasma after 6 hours, while the methylated fragment was detectable even after 24 hours. In animals with tumour, both amplicons were detectable after 24 hours.

Conclusion: The examination of the role and mechanism of cfDNA shows an increasing level of interest. This work can contribute to a better understanding of the release and degradation of cfDNA.

Keywords: cell-free DNA, DNase activity, xenograft model, plasma

Barták BK, Nagy ZsB, Spisák S, Tulassay Zs, Dank M, Igaz P, Molnár B. [ In vivo analysis of circulating cell-free DNA release and degradation.] Orv Hetil. 2018; 159(6): 223-233.

(Beérkezett: 2017. szeptember 9.; elfogadva: 2017. október 15.)

\begin{abstract}
Rövidítések
$\mathrm{BCP}=1$-bróm-3-klórpropán; $\mathrm{CpG}$ = citozin-guanin dinukleotid; $\mathrm{CRC}=($ colorectal cancer $)$ vastagbéldaganat; $\mathrm{CT}=($ cycle threshold) áttörési pont; DNMT = DNS-metiltranszferáz; EDTA $=$ etilén-diamin-tetraecetsav; GAPDH = gliceraldehid3 -foszfát-dehidrogenáz; IL = interleukin; MII = Metasztázis Inhibíciós Index; MYOD = miogenikus differenciációban szerepet játszó gén; ND4 = a NADH-dehidrogenáz enzim 4-es alegységét kódoló gén; $\mathrm{NET}=$ (neutrophil extracellular traps) neutrofil extracelluláris csapda; OCA = az okulokután albinizmus génje; PRIMAl = prolingazdag membránhorgony- 1 ; RT-PCR $=$ (real-time polymerase chain reaction $)$ valós idejü polimeráz-láncreakció; SAM = S-adenozil-metionin; SCID = (severe combined immunodeficiency) súlyos kombinált immunhiány; SDC2 = szindekán- 2 ; SEPT9 = szeptin-9; SFRP1 = szekretált frizzled-rokon fehérje-1; SFRP2 = szekretált frizzled-rokon fehérje-2; SHO = SCID Hairless Outbred; skDNS = sejten kívüli DNS; SLE = szisztémás lupus erythematosus; $\mathrm{TLR}=$ (Toll-like receptor) Toll-típusú receptor; $\mathrm{TNF} \alpha=$ tumornekrózisfaktor- $\alpha$
\end{abstract}

A véráramban található szabad, sejten kívüli DNS (skDNS)-molekulák vizsgálata nagy hangsúlyt kap napjainkban, hiszen könnyen elérhetố forrásként szolgál a különböző betegségek, többek között daganatok diagnosztizálására. Egyre nagyobb érdeklődés övezi az ún. folyadékbiopszia (liquid biopsy) mintavételi eljárást, mivel segítségével lehetséges, hogy egy egyszerú vérvétel után információt szerezzünk a tumoros betegségek aktuális állapotáról. A módszer alapjául a daganat szövetéből származó, aberráns genetikai és epigenetikai változásokat tartalmazó szabad DNS-frakció vizsgálata szolgál. Számos tanulmány foglalkozik a szabad DNS-frakció mennyiségi és minőségi jellemzőinek elemzésével, azonban a származására, funkciójára és stabilitására vonatkozó elméletek mindmáig bizonytalanok.

Először az 1940-es években Mandel és Metais figyelte meg, hogy a véráramban cirkuláló DNS- és RNS-molekulák találhatók [1]. Később számos elváltozás esetén leírták a szabad DNS jelenlétét a vérben, úgymint gyulladásos és autoimmun betegségekben, cukorbetegségben vagy daganatokban, és emelkedett koncentrációját is rövidesen az 1980-as években detektálták [2,3]. Leon és mtsai áttétképzés esetén $209 \pm 39 \mathrm{ng} / \mathrm{ml}$ skDNS-kon- centrációt írtak le, ellenben metasztázis hiánya esetén csupán $100 \pm 30 \mathrm{ng} / \mathrm{ml}$ mennyiséget állapítottak meg [2]. Egészséges személyekben a szintje jóval alacsonyabb tartományban mozog $(1,8-44 \mathrm{ng} / \mathrm{ml})$, a mennyisége azonban jelentősen emelkedik nemcsak daganatos megbetegedések esetén, hanem többek között erőteljes fizikai aktivitás vagy a terhesség első trimesztere során [4, 5]. Méretét tekintve a szabad DNS elég tág határok között mozog, elektroforetikus módszerek alapján 180 bp és 10000 bp közötti tartományba esik [6]. Rákos megbetegedések esetén több módon is bekerülhet a szabad DNS a keringésbe. Lehetséges az egészséges és a tumoros sejtekből való felszabadulás is, ellenben az, hogy a szabad DNS mennyiségének mekkora hányada és milyen ütemben kerül a vérbe a daganatból és az egészséges sejtekből, napjainkig bizonytalan. Az skDNS felszabadulása történhet nekrotizáló daganatsejtekből, apoptózison átesett sejtekből apoptotikus testeken keresztül történő kijutás segítségével, illetve aktív szekrécióval is [7]. A legvalószínúbb azonban, hogy ezek a folyamatok együttesen zajlanak le a szervezetben. Továbbá a lymphocyta sejtekról bebizonyosodott, hogy képesek in vitro DNSmolekulák kibocsátására $[8,9]$, valamint a neutrofil granulocyták extracelluláris neutrofilcsapdákat (NET - neutrophil extracellular traps) ürítenek a vérbe, melyek többek között mitokondriális és genomiális DNS-fragmentumokat is tartalmazhatnak $[10,11]$. A NETózis folyamata elsősorban a patogének elleni védekezés során játszódik le, de megfigyelték szisztémás lupus erythematosusban (SLE) szenvedő betegek vérében is [12]. A szabad DNS ezeken kívül többféle formában jelen lehet a vérben: szabadon, kapcsolódhat sejtmembránrészekhez, DNS-kötő fehérjékhez, és különböző vesiculákban vagy virtoszómákban is megtalálható [13]. Ismert az is, hogy az exoszómákhoz köthető DNS-molekulák nagyobb mérettartományban a membránhoz kapcsolt formában találhatók, a kisebb méretû szakaszok azonban az exoszómák belsejében helyezkednek el [14-16]. Az skDNS újgenerációs szekvenálási módszerekkel történő vizsgálata során igazoltak gazdaszervezeti idegen (non-host vagy nem humán eredetû) szekvenciák jelenlétét is, amelyek az elfogyasztott táplálékból, valamint a szervezetben élő mikrobákból kerülnek a véráramba. Ezeknek a 
molekuláknak pontos keringésbe kerülési mechanizmusa és biológiai szerepe nem ismert, az összes skDNS-menynyiséget tekintve jelenlétük $1 \%$ alatti, átlagos mennyiségük $0,45 \%$ körüli értéket mutat $[17,18]$.

A daganatokban a szabad DNS megnövekedett menynyiségét a felborult nukleinsav-metabolizmus mellett a DNS végleges lebontását elvégző endo- és exonukleázaktivitással rendelkező DNáz enzimek mérsékelt müködése is okozhatja. Emellett a DNáz-inhibitorok megemelkedett mennyiségét is megfigyelték [19]. A DNáz-I enzim mint potenciális antitumor ágens amellett, hogy csökkenti az skDNS mennyiségét, gátolja a tumorsejtek proliferációját és rontja a metasztatizáló képességet is $[6,19]$. Egereken végzett kísérletek bizonyították, hogy DNáz-kezelés után a tumoros állatok vérplazmájában az alacsony DNáz-aktivitás és a megemelkedett skDNSmennyiség visszatér a normál, fiziológiás szintre [20].

Egyes tanulmányok leírták, hogy az skDNS felvételre is kerülhet bizonyos sejtek által. Anker és mtsai megfigyelték, hogy egér fibroblast sejtek tumorossá alakulnak humán colorectalis adenocarcinoma sejtvonal (SW480) felülúszójával történő inkubálás után [21]. García-Olmo és mtsai 2001. évi közleménye szerint az onkogéneket tartalmazó szabad DNS-molekulák távoli szövetekbe eljutva transzformálhatják azokat, ezáltal hozzájárulva a metasztázisok kialakulásához. Ezt a folyamatot genometasztázisnak nevezzük [22].

Látható, hogy az skDNS koncentrációja többféle fiziológiás és kóros folyamat során is megemelkedik [23]. Ezért tumoros betegek esetén a szabad DNS szintjének változása önállóan nem reflektál a daganat típusára. A tumor szövetéből kijutó DNS azonban olyan tulajdonságokkal bír, amelyek kifejezetten egy adott tumorra jellemzőek, úgymint szomatikus mutációk, rendellenes mikroszatellita-mintázat és olyan epigenetikai változások, mint a tumorspecifikus DNS-metilációs mintázat változása [24]. A vastagbélrák (CRC) kialakulásában a KRAS-, az APC- és a TP53-gén mutációjának alapvető szerepe van [25]. Ám annak ellenére, hogy a tumorszöveti mintákban magas százalékban megfigyelhető ezeknek a géneknek a mutációja, a vérmintákban kisebb hányadban mutathatók ki ezek a genetikai eltérések [26]. Wang és mtsai a KRAS-, az APC- és a TP53-gén mutációját elemezték vastagbélrákos betegek szöveti és szérummintáiban. A 3 génből legalább egy mutált volt a rákos szövetek $75 \%$-ában, ezzel szemben a 3 gén a szérummintáknak mindössze 30,4, 34 és 34,2\%-ában volt mutáns [27].

A DNS-metiláció az egyik leggyakoribb epigenetikai módosítás, amely egy metilcsoport kapcsolódását jelenti a citozin pirimidingyuúrüjének 5. szénatomjához. A reakciót DNS-metiltranszferáz (DNMT) enzimek katalizálják. A DNS-metiláció funkciója a génexpresszió szabályozása, a gének promóter régiójában történő fokozott hipermetiláció a $\mathrm{CpG}$ dinukleotidokban gazdag régiókon (ún. CpG-szigeteken) a transzkripció csökkenését vagy gátlását okozza $[28,29]$. A DNS-molekulák meti- lációs mintázata a tumorból kikerülve az skDNS-en is megmarad, ezért a különböző metilációs markerek azonosítása a vérben nagy segítséget nyújthat a daganatok felismeréséhez. A kereskedelmi forgalomban kapható első diagnosztikai rendszer vastagbéldaganat esetén az EpiGenomics cég által kifejlesztett szeptin-9 (SEPT9)génszakasz vizsgálatán alapuló Epi proColon vérteszt. A szeptinek családjába evolúciósan konzervált, GTP-kötő, P-hurokkal rendelkező filamentképző fehérjék tartoznak. Vastagbéldaganat esetében hipermetilálódó szeptin-9 génszakaszt is tartalmazó DNS-darabok kerülnek ki a véráramba, amelynek metilációs állapotát határozza meg a perifériás vérrel elvégezhető teszt. A teszt érzékenysége 68-72\%, specificitása $80 \%$ körüli daganat esetén, azonban rákelőző állapotokban a szenzitivitása jóval alacsonyabb $(30,8 \%)$ [30-33]. A SEPT9-gén mellett számos egyéb metilációs markert írtak már le, melyek különböző érzékenységgel képesek jelezni a vastagbéladenomát és -daganatot $[26,34]$. Kutatócsoportunk az SFRP1-, az SFRP2-, az SDC2- és a PRIMAl-gén metilációs állapotát vizsgálta plazmamintákban. A 4 gén panelként alkalmazva 91,5\%-os szenzitivitással és 97,3\%-os specificitással képes elkülöníteni a tumoros mintákat az egészséges kontrolloktól, és az adenomás betegek plazmamintáinak több mint $80 \%$-ában is kimutathatók a metilációs eltérések [35]. Látható tehát, hogy a metilációs elváltozások magasabb arányban találhatók meg a véráramban, mint a mutációk, ennek okai azonban bizonytalanok. Továbbá az sem tisztázott, hogy az elváltozásokat hordozó szabad DNS-molekulák mennyire stabilak a véráramban, és hogy a véráramba kerülés után mennyi ideig azonosíthatók.

A jelen tanulmányban az skDNS felszabadulásának és lebomlásának nyomon követését tûztük ki célul. A szabad DNS felszabadulásának vizsgálatához SHO-egér/ humán HT-29 colorectalis adenocarcinoma sejtvonal xenograftmodellt alkalmaztunk. A vérplazmából izolált egér/humán skDNS arányának meghatározásával megállapítható, hogy a DNS mekkora hányada származik a tumoros sejtekből, és ennek mennyisége hogyan változik a daganat fejlődésének előrehaladtával. A degradáció elemzését in vitro körülmények között felszaporított, majd egerek véráramába juttatott, mesterségesen metilált es nem metilált DNS-molekulákon végeztük.

\section{Anyagok és módszerek}

\section{A sejten kivüli DNS felszabadulásának elemzése}

Munkánk során célunk az skDNS eredetének, felszabadulási ütemének és sebességének nyomon követése és elemzése volt. Ehhez 8 héten keresztül tartó kísérletet végeztünk egér/humán HT-29 tumor xenograftmodell segítségével. Bioinformatikai úton kiválasztott és kísérletesen validált egér és humán gének kópiaszámát vizsgálva következtettünk a vérben megjelenő humán DNS menynyiségére, melynek növekedését mértük az idő előreha- 

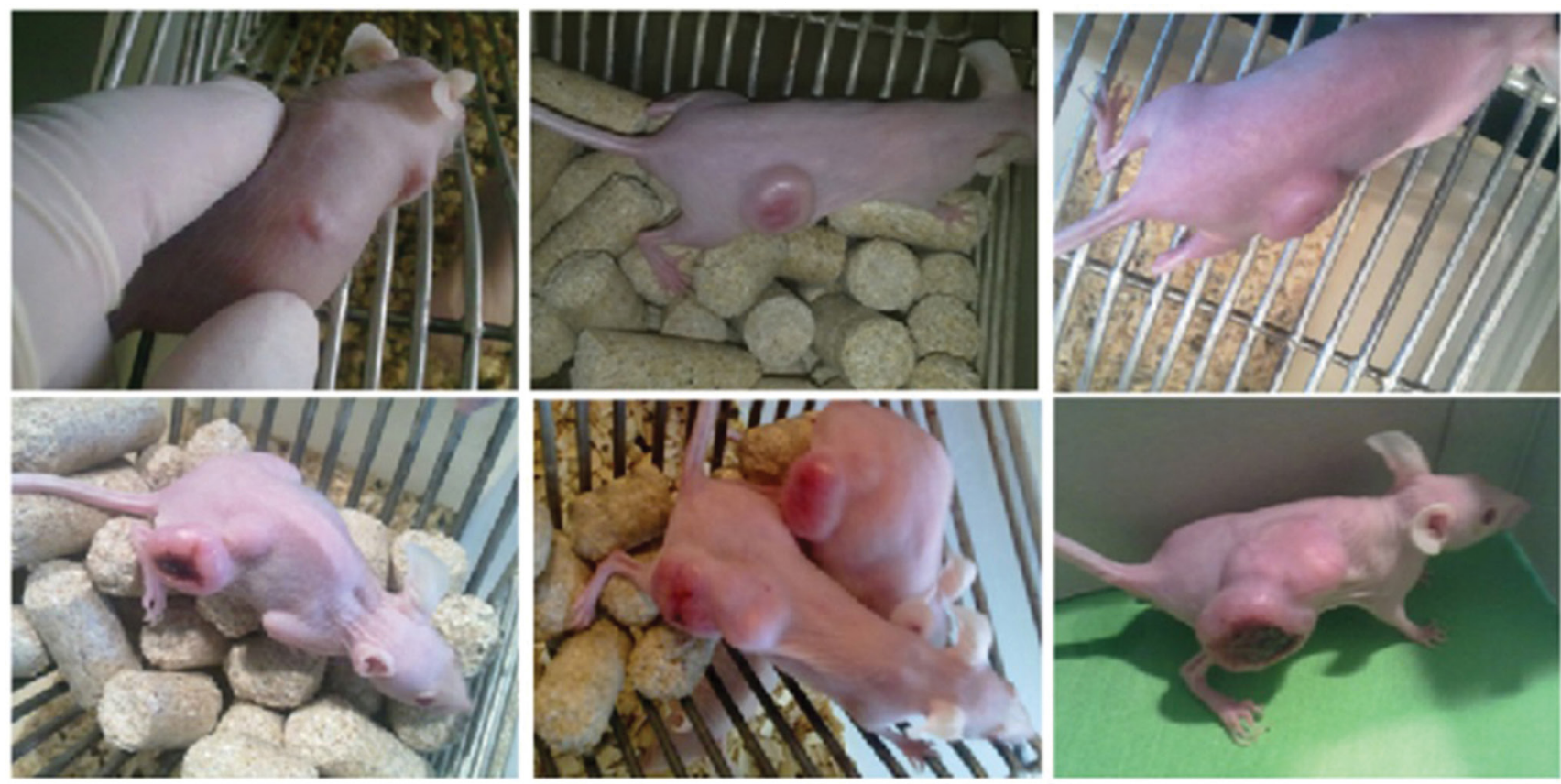

1. ábra

| Xenograft-tumormodell kialakítása: 7. nap, 21. nap, 28. nap, 42. nap, 56. nap és 63. nap

ladtával. Az eredmények révén megállapítottuk a humán tumorsejtekből a véráramba kerülő skDNS-ek arányát, ezáltal mérhettük a felszabadulás ütemét.

\section{Xenograftmodell előállítása, vérvétel, DNS-izolálás}

A sejten kívüli szabad DNS felszabadulásának ütemét SHO-egér/humán HT-29 colorectalis adenocarcinoma sejtvonal xenograftmodell segítségével vizsgáltuk. Az SHO- (SCID Hairless Outbred) egerek homozigóták a $P r k d c^{\text {sid }}$ - és a $H r^{\mathrm{hr}}$-mutációkra nézve, ezért ezek az állatok albínók, szőrtelenek és immundeficiensek (1. ábra). A HT-29 sejtvonalból származó sejtek subcutan oltva könnyen osztódnak az állatokban, és több cm-es tumort alakítanak ki. Munkánk során nyolc SHO-egeret oltottunk $5 \times 10^{6}$ HT-29 sejtvonalból származó sejttel subcutan, majd 8 héten keresztül vettünk vért $(\sim 200 \mu \mathrm{l})$ az állatoktól szemzugvénán keresztül steril EDTA/PBS (l×) csövekbe, és azt a feldolgozásig jégen tároltuk. Ezután plazmafrakciót szeparáltunk két lépésben, először 10 percig $2000 \mathrm{rpm} 4{ }^{\circ} \mathrm{C}$-on centrifugáltunk, majd a felülúszó leszívása után 10 percig $4000 \mathrm{rpm} 4{ }^{\circ} \mathrm{C}$-on. A plazmát további felhasználásig $-20{ }^{\circ} \mathrm{C}$-on tároltuk. A szabad DNS-frakció kinyeréséhez a QIAamp Circulating Nucleic Acid Kitet használtuk (Qiagen, Németország), a „Purification of Circulating DNA from $1 \mathrm{ml}$, $2 \mathrm{ml}$, or $3 \mathrm{ml}$ Serum or Plasma" protokoll gyártói leírása szerint. A DNS eluálása $150 \mu \mathrm{l}$ PCR-tiszta desztillált vízzel történt két lépésben. Az skDNS koncentrációjának megállapítására Qubit 1.0 fluorométert alkalmaztunk (Thermo Fisher Scientific, USA) a Qubit dsDNA High Sensitivity Assay Kittel. Az izolált DNS-t $4{ }^{\circ} \mathrm{C}$-on tároltuk.

\section{Primerek tervezése, valós idejű PCR}

A véráramban található szabad DNS egér/humán arányának megállapítására 6 egér és 6 humán genomiális és mitokondriális gén kópiaszámát vizsgáltuk (1. táblázat). A primerek tervezése Primer3 programmal történt, és a fó szempont a tervezéskor a magas fokú fajspecificitás volt. Az oligonukleotidokat egységesen $100 \mu \mathrm{M}$-os (100 $\mathrm{pmol} / \mu \mathrm{l})$ törzsoldatra hígítottunk. A polimeráz-láncreakció az izolált DNS-mintán kívül tartalmazott $5 \mu \mathrm{l}$ LightCycler ${ }^{\circledR} 480$ Probes Master mixet $(2 \times)$ (Roche Applied Science, Svájc); a tervezett primereket $200 \mathrm{nM}$ végkoncentrációban; és 50× SYBR Green I interkalálódó festéket (Thermo Fisher Scientific) a gyártói utasításoknak megfelelően. A primerpárok tesztelésére in silico a BiSearch szoftvert használtuk (http://bisearch.enzim. hu) [36]. A PCR-t LightCycler 480 típusú real-time PCR-készülékkel (Roche Applied Science) végeztük, és a reakció során 384 lyukú multiwell plate-eket használtunk, melyekbe a pipettázás Eppendorf epMotion 5070 pipettázóautomatával (Eppendorf, Németország) történt. Minden plate tartalmazott nyolc mintát duplikátumban, PCR-tisztaságú desztillált vizet negatív kontrollként, valamint egy 7 tagból álló kalibrációs hígítási sort. Ehhez viszonyítva tudtunk következtetni az egér/ humán DNS arányára, és megállapíthattuk a kísérleti modellünk érzékenységét.

A hígítási sor felállítása során különböző arányban elegyítettünk egérvérből, illetve HT-29 sejtvonalból származó sejtekból izolált DNS-t. A DNS izolálása a HT-29 sejtkultúrából a High Pure PCR Template Preparation Kit (Roche Applied Science) „Isolation of Nucleic Acids from Mammalian Whole Blood, Buffy Coat, or Cultured Cells" protokoll alapján a gyártó utasításai szerint tör- 
1. táblázat |Az egér/humán DNS arányának meghatározására használt 6 egér és 6 humán mitokondriális és genomiális génre tervezett primerek szekvenciái

\begin{tabular}{|c|c|c|}
\hline A gén neve & Forward primerszekvencia & Reverse primerszekvencia \\
\hline$e 12 S$ & AGGTTTGGTCCTGGCCTTAT & CGGTCTATGGAGGTTTGCAT \\
\hline el6S & GGGATAACAGCGCAATCCTA & ATTGGGATGTCCTGATCCAA \\
\hline eMT_6836 & CACATTCGAGGAACCAACCT & CCAATTTTAGGGGGTTCGAT \\
\hline eND4 & GGAACCAAACTGAACGCCTA & ATGAGGGCAATTAGCAGTGG \\
\hline$e T N F \alpha$ & TGTTGCCTCCTCTTTTGCTT & TGGTCACCAAATCAGCGTTA \\
\hline eTLR5 & GCСТCTAAGGGCTCTCACСТ & TGGAGGGAAACCATGTCATT \\
\hline b12S & ACCACCTCTTGCTCAGCCTA & CATGGGCTACACCTTGACCT \\
\hline blos & GTACCGCAAGGGAAAGATGA & TTGGCTCTCCTTGCAAAGTT \\
\hline hMT_15195 & TATCCGCCATCCCATACATT & GTGTGAGGGTGGGACTGTCT \\
\hline hND4 & CGCCTCACACTCATTCTCAA & TGTTTGTCGTAGGCAGATGG \\
\hline hMYOD_l & GGAAGCAGCTGGTACTGGTC & GGGCAGGGACTGATTCACTA \\
\hline hOCA2_3 & CCTCAGGACCCTGTGATGAT & TTTCAAGGTGCCCAGATTTC \\
\hline
\end{tabular}

tént. A vérből történő izolálás a következő protokollt követve valósult meg: $300 \mu \mathrm{l}$ vérhez pipettáztunk $500 \mu \mathrm{l}$ $2 \%$ SDS-t (Sigma-Aldrich, USA) és $100 \mu$ ProteinázK enzimet (Qiagen), majd inkubáltunk 10 percig $60^{\circ} \mathrm{C}$-on Eppendorf Thermomixer Comfort-ban (Eppendorf). Ezután $500 \mu \mathrm{l}$ telített fenolt (Sigma-Aldrich) és $100 \mu \mathrm{l}$ BCP-t (Sigma-Aldrich) adtunk az elegyünkhöz, majd 10 percig 8000 rpm-en centrifugáltunk. A felülúszó leszívása után, a nukleinsav-frakció kicsapása 70v/v\% izopropanollal történt. A DNS tisztításához QIAamp Genomic DNA Minikit (Qiagen) oszlopot alkalmaztunk, majd QIAvac 24 Plus vákuumszivattyút (Qiagen) használtunk. A mosási lépések során kétszer 70\%-os etanollal ( $1-1 \mathrm{ml})$, majd egyszer abszolút etanollal $(700 \mu \mathrm{l})$ mostuk az oszlopot. A szárítás során 3 percig 20000 rpm-en centrifugáltunk, majd eluáltuk a DNS-t kétszer $75 \mu \mathrm{l}$ PCR-tiszta desztillált vízzel. Az izolált DNS-minták koncentrációjának mérése NanoDrop-1000 (Thermo Fisher Scientific) spektrofotométerrel történt. A mérés után a mintákat $1 \mu \mathrm{g} / \mathrm{ml}$-es végkoncentrációra hígítottuk, mert előzetes méréseink alapján a plazma DNS-koncentrációja ebben a tartományban mozog. A különböző arányú egér/humán elegyeket a 2. táblázat szerint állítottuk össze.

2. táblázat | A humán és egér-DNS \%-os aránya az elegyítés során a 7 tagból álló hígítási sor felállításához

\begin{tabular}{cl}
\hline Humán DNS aránya (\%) & Egér-DNS aránya $(\%)$ \\
\hline 0,03 & 99,97 \\
0,1 & 99,9 \\
0,4 & 99,6 \\
1,5 & 98,5 \\
6,25 & 93,75 \\
25 & 75 \\
100 & 0 \\
\hline
\end{tabular}

A polimeráz-láncreakció során az alábbi programot használtuk: denaturálás $95^{\circ} \mathrm{C} 5 \mathrm{~min}$; amplifikáció $95^{\circ} \mathrm{C}$ $10 \mathrm{~s}, 60{ }^{\circ} \mathrm{C} 10 \mathrm{~s}, 72{ }^{\circ} \mathrm{C} 10 \mathrm{~s} 50$ ciklusban ismételve; olvadáspont-analízis folyamatos emelkedéssel $95{ }^{\circ} \mathrm{C} 5 \mathrm{~s}$; hütés $65^{\circ} \mathrm{C} 1$ min és $40^{\circ} \mathrm{C} 30 \mathrm{~s}$. A képződött termékek specificitását és tisztaságát a ciklus végén zajló olvadáspont- (melting curve) analízissel ellenőriztük. A reakcióhoz használt interkalálódó SYBR Green I festék gerjesztéséből származó fluoreszcencia emisszióját képes detektálni a PCR-készülék, ami arányos a keletkezett kétszálú DNS mennyiségével. A mért fluoreszcenciaintenzitásokat a ciklusszámok függvényében grafikusan ábrázolja a készülékhez tartozó szoftver (LightCycler 480 Software release 1.5.0). Végeredményként az amplifikációs görbék második deriváltjának maximumaként kalkulált CT- (cycle threshold) értéket (áttörési pont) kapjuk meg, melynek segítségével megállapíthatjuk a kiindulási templát DNS-koncentrációját - ebből következtetni tudtunk az egérháttérben lévő humán HT-29 sejtekből származó DNS mennyiségére.

\section{A sejten kíüli DNS degradációjának vizsgálata}

Vizsgálatunk során célunk mesterségesen létrehozott, majd egerek véráramába juttatott DNS-szakasz bomlékonyságának tanulmányozása volt. A vizsgálatot metilált és nem metilált DNS-fragmentumokkal egészséges és C38-as tumorsejttel oltott egereken végeztük. Specifikus RT-PCR-próbák használatával figyeltük meg a DNS degradációjának folyamatát, és következtetéseket vontunk le a DNáz enzimek múködésére és a DNS stabilitására vonatkozóan.

\section{C38-as tumormodell előállítása}

A szabad DNS stabilitásának vizsgálatára C57BL/6-os egértörzsből származó egereket használtunk. Négy egészséges és négy C38 egér colorectalis adenomacarci- 
3. táblázat |A mesterségesen létrehozott, egerek véráramába juttatott PCR-termékre tervezett primerek szekvenciái

\begin{tabular}{|c|c|c|}
\hline A PCR-próba szimbóluma & Forward primerszekvencia & Reverse primerszekvencia \\
\hline$\underline{G D H X 1}$ & TTAGGAAAGCCTGCCGGTGA & GTCAGCGTCAGAGCCCAGTG \\
\hline$G D H \_A$ & CCGGGAGAAGCTGAGTCAT & CACCAGAGGGGCCATTTT \\
\hline$G D H \_B$ & СТСТСТСССАТСССТТСТСС & GAAATCAGGAGTGGGAGCAC \\
\hline GDH_C & TCCTGCCCTTTGAGTTTGAT & CTAGCTCAGCTGCACCCTTT \\
\hline$G D H \_D$ & TGCCTTCTTGCCTCTTGTCT & GTTAAAAGCAGCCCTGGTGA \\
\hline$G D H \_E$ & AAAGCTGGTGTGGGAGGAG & AATTTGCCATGGGTGGAAT \\
\hline$G D H \_E F$ & ССССТTCATACССТCACGTA & GACAAGCTTCCCGTTCTCAG \\
\hline$G D H \_F$ & AАTCССАТСАССАТСТТССА & AGCCACACCATCCTAGTTGC \\
\hline$G D H \_F G$ & TGAGTGGAAGACAGAATGGAAG & GAGATGGGGACAGGACCATA \\
\hline$G D H \_G$ & TATGGTAACCTTGTGTCCCTCA & TTGATTTTGGAGGGATCTCG \\
\hline$G D H \_G H$ & TATGGTCCTGTCCCCATCTC & CTCCATGGTGGTGAAGACG \\
\hline GDH_H & TCCACTGGCGTCTTCACC & CCTTTGCAGGGCTGAGTC \\
\hline$G D H \_H I$ & CCCGGGTTCATAACTGTCTG & TTCACACCCATGACGAACAT \\
\hline$G D H \_I$ & CATCATCTCTGCCCCСТCT & GATGATCTTGAGGCTGTTGTCA \\
\hline$G D H \_I J$ & CATGGGTGTGAACCATGAGA & CAAGTCAGGGGAGCGTGT \\
\hline$G D H \_J$ & CCTGGCACCCTATGGACA & AGGCATTGCTGCAAAGAAAG \\
\hline$G D H \_K$ & GGGACTGGCTTTCCCATAAT & TGTGGTCTGCAAAAGGAGTG \\
\hline$G D H \_L$ & AAGGTCATCCCTGAGCTGAA & AGGTCCACCACTGACACGTT \\
\hline$G D H \_M$ & CGACCACTTTGTCAAGCTCA & AGAGTTGTCAGGGCCCTTTT \\
\hline GDH_N & GGGAGGGACCTGGTATGTTC & AAATGGTTCTCGAAGCAAGC \\
\hline
\end{tabular}

noma sejtvonalból származó tumorsejtekkel oltott állatot vizsgáltunk. Az egerekre a C38 törzstenyészetből származó $5 \times 5 \times 5$ mm-es nem nekrotizáló tumorszövetdarabokat subcutan oltottuk, majd a kezelést az oltást követő 21 . napon végeztük.

\section{DNS izolálása, mesterséges DNS-szakasz létrehozása, tisztítása}

A vizsgálatot HT-29 humán colorectalis adenocarcinoma sejtvonalból történő DNS-izolálással kezdtük, High Pure PCR Template Preparation Kittel (Roche) az „Isolation of Nucleic Acids from Mammalian Whole Blood, Buffy Coat, or Cultured Cells" protokoll szerint a gyártó utasításait követve. A kinyert DNS-sel PCR-t végeztünk Eppendorf Mastercycler ep Gradient S PCR-készülékkel (Eppendorf) $50 \mu$ térfogatban, amely tartalmazta a $2 \times$ LightCycler Probes Master mixet (Roche), az $5 \times \mathrm{Q}$ puffert (Qiagen), a 20 ng HT-29 sejtvonalból izolált DNS-templátot és a tervezett primert. A primerek tervezése Primer3 programmal történt, az előzetesen kiválasztott, felszaporítandó gliceraldehid-3-foszfát-dehidrogenáz (GAPDH) gén körülbelül 3000 bp méretű szakaszára (GDH_Xl) (3. táblázat). A PCR hőciklusai a következők voltak: denaturálás $94{ }^{\circ} \mathrm{C} 5 \mathrm{~min}$; amplifikáció $94{ }^{\circ} \mathrm{C} 3 \mathrm{~s}, 60,5^{\circ} \mathrm{C} 30 \mathrm{~s}$, majd $72{ }^{\circ} \mathrm{C} 3$ min 35 ciklusban; extenzió $72{ }^{\circ} \mathrm{C} 2 \mathrm{~min}$, végül $4{ }^{\circ} \mathrm{C}$. A reakciótermékeket etídium-bromid interkalálódó festéket tartalmazó 1\%-os agaróz-gélelektroforézissel ellenőriztük. A min- tákat kontroll-DNS (létra) mellett $70 \mathrm{~V}$ feszültségen 30 percig választottuk el. A DNS láthatóvá tétele UV fény használatával történt. A felszaporított DNS-szakasz tisztítása során a PCR-termékhez $80 \mathrm{v} / \mathrm{v} \%$ ACL puffert (Qiagen), 180v/v\% ACB puffert (Qiagen) és 140v/v\% izopropanolt adtunk, majd $-20{ }^{\circ} \mathrm{C}$-on 14 órán keresztül inkubáltunk. Ezután a DNS-mintát vákuummódszerrel QIAamp Mini oszlop (Qiagen) és QIAvac 24 Plus vákuumszivattyú segítségével tisztítottuk és nyertük vissza. A mosást 1 -1 ml $2 \times 70 \%$-os, majd $1 \times$ abszolút etanollal

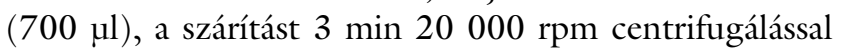
végeztük. Ezután az eluálás PCR-tiszta vízzel történt $150 \mu$ l-ben. A koncentráció mérésére NanoDrop-1000 (Thermo Fisher Scientific) spektrofotométert alkalmaztunk.

\section{A PCR-termék metilálása}

A tisztított PCR-terméket 2 db egészséges és 2 db tumoros egérnek metilált formában injektáltuk, a másik csoportba tartozó egerek nem metilált formában kapták a PCR-terméket. Az in vitro metilálás során $1 \mu g$-nyi PCR-termékhez $1 \mu$ l SssI. CpG-metiltranszferáz (4 U/ $\mu \mathrm{l})$ enzimet (BioLabs, New England), $3 \mu \mathrm{l} 1 \times \mathrm{NE} 2$ puffert és $160 \mu \mathrm{M}$ végkoncentrációjú $S$-adenozil-metionint (SAM) adtunk, majd a reakciót egy órán keresztül $37{ }^{\circ} \mathrm{C}$-on, majd 20 percig $65^{\circ} \mathrm{C}$-on inkubáltuk. A tisztítást, majd a koncentráció mérését a fentebb leírt módon újra elvégeztük. 


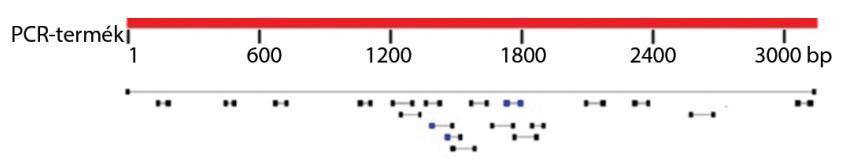

2. ábra

Az egerek véráramába juttatott, 3000 bp méretű humán PCR termékre tervezett specifikus primerpárok és a 19 amplikon elhelyezkedése

\section{PCR-termékkel történő kezelés, vérvétel és DNS-izolálás}

Hétszáz mikroliter tisztított PCR-terméket tartalmazó oldathoz $700 \mu \mathrm{l}$ PBS-t $(2 \times)$ pipettáztunk, majd ebből 300-300 $\mu 1-t$ (100 ng tisztított összes DNS) injektáltunk 2 egészséges és 2 tumoros egér farkának vénájába. A további 4 egeret a metilált PCR-termékkel kezeltük azonos módon.

A $8 \mathrm{db}$ egértől 5 alkalommal vettünk vért, közvetlenül a kezelés előtt, majd a kezelés után 1, 3, 6 és 24 h-val. A vérvétel szemzugvénán keresztül történt, steril EDTA/ PBS $(\mathrm{l} \times)$ csövekbe, melyeket a plazmafrakció szeparálásáig jégen tároltunk. A frakció kinyeréséhez 10 perc $2000 \mathrm{rpm} 4{ }^{\circ} \mathrm{C}$-on történő centrifugálást követően a felülúszót leszívtuk, majd újra centrifugáltuk 10 percig $4000 \mathrm{rpm} 4{ }^{\circ} \mathrm{C}$-on. A plazmamintákat $-20{ }^{\circ} \mathrm{C}$-on tároltuk. A szabad DNS-frakció izolálását a QIAamp Circulating Nucleic Acid Kittel végeztük (Qiagen), a „Purification of Circulating DNA from $1 \mathrm{ml}, 2 \mathrm{ml}$, or $3 \mathrm{ml}$ Serum or Plasma" protokoll alapján a gyártói leírás szerint.

\section{Primerek tervezése és valós idejú PCR}

A plazmafrakcióból izolált DNS-mintákra 19 specifikus, egyenletesen elhelyezkedő és egymással átfedő PCRpróbát használtunk a 3000 bp méretû́ bejuttatott humán DNS-szakasz kimutatására (2. ábra, 3. táblázat). A primerek tervezése Primer3 program segítségével történt. A 19 próba validálására egy 4 tagból álló hígítási sort mértünk össze a tisztított PCR-termékekból, 200×-os kezdeti hígítással, majd 3-szor 80× lépésekkel. Ezután határoztuk meg a reakciók hatásfokait. A valós idejú PCR-t a fentebb leírt módon végeztük a 19 PCR-termékre tervezett primerrel és $5 \mathrm{db}$ kontroll-, egér-DNSre tervezett primerrel: eIL6, eTNF $\alpha$, eTLR5, eTLR9, el8S (4. táblázat). Elózetes tesztelés során bizonyítottuk, hogy ezek a primerek a humán DNS-t nem szaporít- ják fel, így ezekhez viszonyítva kvantifikálhattuk a kísérleti rendszert.

A $8 \mathrm{db}$ egértől 5 alkalommal levett vérből izolált DNSmintát 3 párhuzamos reakcióban vizsgáltuk desztillált vizes negatív kontroll mellett. Az eredményként kapott CT-értékekből következtettünk a degradáció mértékére, és összehasonlíthattuk az egészséges és a tumoros, illetve a metilált-nem metilált PCR-termék bomlásának ütemét.

\section{Eredmények}

\section{Az skDNS-felszabadulás vizsgálata}

Az egér- és a humán szervezetek genomjai között igen nagyfokú a hasonlóság (70-80\%), ami jelentősen nehezítette a kvantifikációt, hiszen viszonylag magas egérDNS- „háttérben” kellett azonosítani, elkülöníteni és kimutatni a nagyságrendekkel kisebb kópiában megjelenő és jelen lévő HT-29-eredetû skDNS-t. Ehhez RT-PCRalapú megközelítést használtunk érzékenysége és specifikussága miatt. A vizsgálat során 6 egér és 6 humán mitokondriális (4-4) és genomiális (2-2) próbával dolgoztunk. A gének kiválasztása többszörös szekvenciaillesztés után történt, s ennek során olyan régiókat kerestünk, amelyek specifikusan vagy csak a humán, vagy csak az egér-DNSben találhatók. Az egér/humán DNS-hígítási soron történó tesztelések azonban azt mutatták, hogy a magas hasonlóság miatt keresztreakciók adódnak. Ezért azokat a primerkombinációkat tartottuk meg, amelyek múködését a másik faj DNS-e nem befolyásolta. Egy 7 tagból álló hígítási sor segítségével állapítottuk meg a módszer érzékenységét. A DNS-mintákat $1 \mu \mathrm{g} / \mathrm{ml}$-es végkoncentrációra hígítottuk, mivel előzetes kísérleteink szerint a plazma-DNS-koncentráció ebben a tartományban mozog. Ezután végeztük az elegyítést a 2. táblázat szerint, majd a RT-PCR alkalmazásával megkapott áttörési pontokat elemeztük. Ezeket az értékeket a ciklusszámból (50) levonva ábrázoltuk annak érdekében, hogy a kapott értékek arányosak legyenek a kópiaszámmal (3. ábra). Az eredmények alapján megállapítottuk, hogy a módszer olyan érzékenységú, hogy nagy biztonsággal képes kimutatni az 1\%o-es humán DNS-tartalmat az egérplazmamintákból. Mindegyik mintát a genomiális DNS mért értékével normalizáltuk, majd a kalibrációs sorok egyeneseinek egyenletével meghatároztuk a humán DNS-tar-

4. táblázat |A plazmaminták DNS-tartalmának pontos meghatározásához használt primerek szekvenciái

\begin{tabular}{l|l|l}
\hline A gén neve & Forward primerszekvencia & Reverse primerszekvencia \\
\hline eIL6 & CTAGCCAGATGGTTTCTTGGA & ATATTTAAATTAGCAATTCATTGAGGT \\
$e T N F \alpha$ & TGTTGCCTCCTCTTTTGCTT & TGGTCACCAAATCAGCGTTA \\
$e T L R 5$ & GCCTCTAAGGGCTCTCACCT & TGGAGGGAAACCATGTCATT \\
$e T L R 9$ & CGGGGACCTACAGCAGAATA & CGGGAACCAGACATGAAGAT \\
elsS & GCAATTATTCCCCATGAACG & GGGACTTAATCAACGCAAGC \\
\hline
\end{tabular}


Hígítási sor

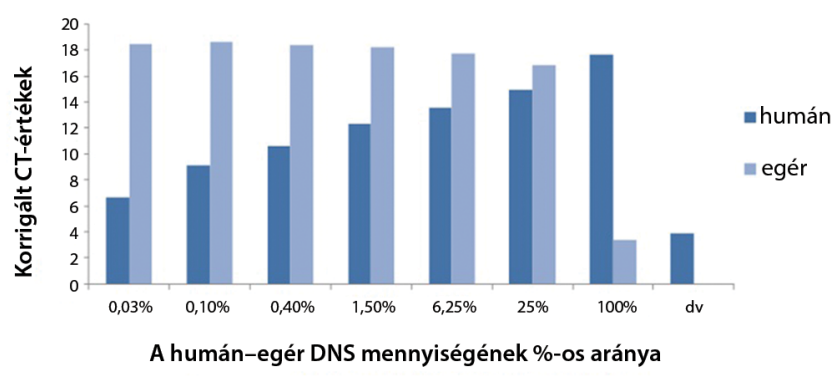

3. ábra

A humán és egér-DNS mennyiségének százalékos aránya az ele gyítés után. A végkoncentráció $1 \mathrm{ng} / \mu \mathrm{l}$. A módszer érzékenységét tekintve képes kimutatni 1\%o-es humán DNS-tartalmat az egérplazmamintákban (dv: desztillált víz, negatív kontroll)

\section{Az skDNS felszabadulásának üteme}

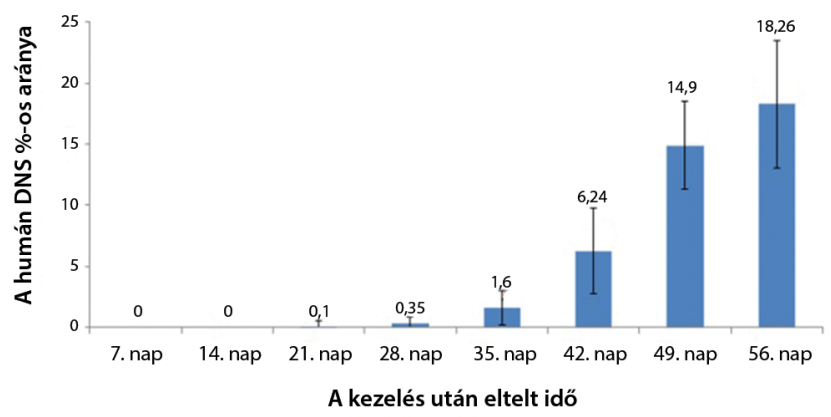

4. ábra

HT-29-es tumorsejtekből származó humán skDNS megjelenésének \%-os aránya. Az SHO-egerekre oltott humán tumorból származó DNS a 8 . hétre 18,26\%-ra emelkedett

talmakat, amelyeket minden mintára átlagoltunk. Az átlagértékeket ezután a szórásértékek feltüntetésével ábrázoltuk. A plazmában található DNS-mennyiségekkel történő korrekciót követően kapott eredményeket a 4. ábra szemlélteti.

A HT-29 egerekre történő oltása után a humán skDNS-tartalom az első 2 hétben a kimutathatósági határ alatt volt, a 3 . hét végére viszont már elérte a $0,1 \%$-os arányt. A következő napokban folyamatos emelkedést tapasztaltunk: az 56. napra a humán DNS aránya elérte a 18,26\%-ot, ami annyit jelent, hogy a véráramban található szabad DNS közel 1/5-e a humán daganatsejtekből származott. Ez tömegarányosnak tekinthető, hiszen az állatok leölésekor a tumor tömege az állatok összsúlyának kb. 20\%-át tette ki.

\section{A metilált és a nem metilált DNS lebomlásának vizsgálata}

A GDH_Xl-es primer alkalmazásával, HT-29 DNStemplátról a 3000 bp méretű terméket fölszaporítottuk és tisztítottuk, majd a kapott minta egy részét in vitro metilálás után, a másik részét metilálás nélkül injektáltuk az egerek farokvénájába. Mindezek után vért vettünk 5 időpontban, és a plazmafrakcióból DNS-t izoláltunk. A plazmaminták DNS-tartalmának pontos meghatározásához 5 egérkromoszóma-pozíciót használtunk (eIL6, eTNF $\alpha$, eTLR5, eTLR9, el8S), amelyekről a korábbi ellenőrzések során bebizonyosodott, hogy a humán DNS-t nem képesek felszaporítani (4. táblázat). Ennek segítségével meghatároztuk a minták DNS-koncentrációját, s az elemzés során a mért ciklusértékekkel korrigáltunk, vagyis két minta közötti különbséget kétszeresnek vettünk, ha az 5 kromoszómapozícióban mért ciklusértékek átlaga 1 ciklussal tért el.

A kísérlet folyamán a 19 PCR-próba (3. táblázat) validálására 4 tagból álló hígítási sort készítettünk a tisztított PCR-termékkel, először 200×-os, majd 3-szor 80×-os hígítási lépésekkel. Az értékelés folyamán kiszámoltuk az $\mathrm{R}^{2}$ korrelációs koefficienst, amely 0,9 és 1 közé esett. A reakciók hatásfokai $\mathrm{E}=81,86-112,75 \%$ között adódtak, az E = $10(-1 / \mathrm{m})-1$ képletet felhasználva, ahol $\mathrm{E}=$ hatásfok, $\mathrm{m}=$ meredekség $(m=[-3,07]-[-3,86])$. Az egyes pozíciók között csekély különbséget tapasztaltunk, ami annak köszönhető, hogy a primerek tapadási környezete minimális mértékben eltérhet energetikai szempontból, így a $60^{\circ} \mathrm{C}$-ra tervezett próbák kissé eltéró áttörési pontot adtak. Az eredmények azonban abba az értéktartományba estek, amelyek megerősítették, hogy a primerek alkalmasak a kvantifikálásra. Az RT-PCR végeredményeként kapott duplikátumok áttörési pontjait átlagoltuk, majd ezeket kivontuk az összesen végrehajtott ciklusok számából (50), hogy a kapott értékek arányosak legyenek a kiindulási DNS-koncentrációval. Következő lépésként a nulladik időponthoz normalizáltuk a rendszert, azaz a kezelés előtt levett vérből izolált DNS CT-értékeiből levontuk az előzőleg megkapott számokat. Utolsó lépésként korrigáltunk a minták közötti koncentrációkülönbségekkel is. A 4 vizsgált esetet - egészséges állat: nem metilált, metilált (5. ábra); tumoros állat: nem metilált, metilált (6. ábra) - grafikonon szemléltettük. Az egerek véráramába injektált DNS-szakasz lebomlásának sebességében különbséget találtunk a nem metilált és a metilált fragmensek között. Ha összevetjük az egészséges egerekből származó minták bomlásának ütemét, láthatjuk, hogy a nem metilált minták esetében 1 óra elteltével a 3000 bp méretû szakasz nagy koncentrációban kimutatható. Ehhez képest a 3 órás mintákban nagyfokú degradációt figyelhetünk meg, ami a 6 órás mintákban tovább fokozódik, a 24 órás mintáknál pedig már olyan mértékű, hogy a kimutathatósági határ alá csökken a fragmentumok jelenléte. A metilált DNS-minta sokkal stabilabbnak mutatkozik, mivel a 3 és a 6 órás mintákból is viszonylag nagy mennyiségben kimutatható az amplikon. A degradáció 24 óra alatt itt is bekövetkezik, azonban a 3000 bp-os molekula bizonyos fragmentumai még megtalálhatók. Összehasonlítva a tumoros és az egészséges egerekből származó mintákat, megfigyelhető, hogy a daganatos mintákból származó nem meti- 
A Nem metilált amplikon degradációja egészséges állatokban

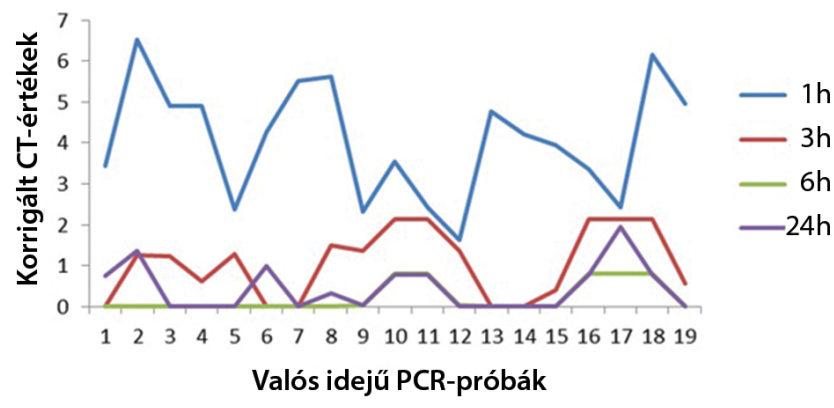

B

Metilált amplikon degradációja egészséges állatokban

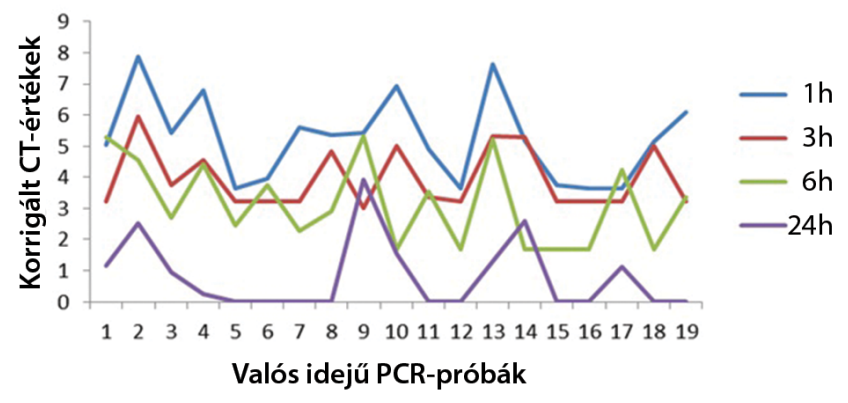

5. ábra $\quad$ Egészséges állatokba injektált nem metilált (A) és metilált (B) amplikonok degradációjának üteme. A metilált fragmentumok stabilabbnak mutatkoztak

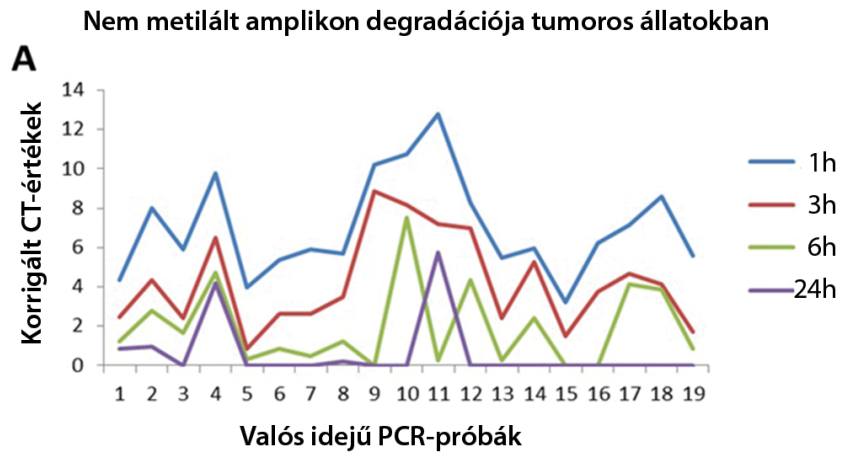

B Metilált amplikon degradációja tumoros állatokban

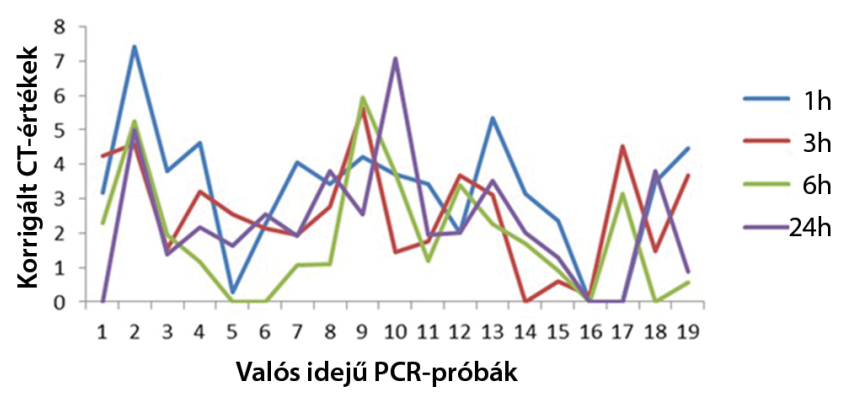

6. ábra

C38-as tumorsejttel oltott állatokba injektált nem metilált (A) és metilált (B) amplikonok bomlásának üteme. A metilált fragmentumok 24 óra elteltével is nagy mennyiségben kimutathatók voltak az egerek plazmamintáiban lált DNS jelen van a kezelés után 6 órával, a metilált fragmentum pedig 24 óra elteltével is egyértelmüen kimutatható nagyobb mennyiségben, mint az egészséges, metilált mintában. Ez összefüggésben áll azzal a feltételezésünkkel, hogy a daganatos betegekben csökkent a DNáz aktivitása, ezáltal tovább kimutatható az injektált DNS-szakasz.

\section{Megbeszélés}

Kísérleteink során a szabad DNS felszabadulását és degradációját elemeztük $\mathrm{SHO}$ - és C57BL/6-os egértörzsek segítségével. Az skDNS felszabadulását SHO-egér/ HT-29 humán colorectalis adenocarcinoma sejtvonal xenograftmodellből származó minták RT-PCR-vizsgálatával határoztuk meg. Első lépésben kiszámítottuk a módszer érzékenységét, s ennek alapján elmondható, hogy az általunk optimalizált módszer nagy biztonsággal mutat ki 0,1\%-nyi humán DNS-t az egérplazmamintákban. Ezt követően megállapítottuk, hogy a xenograftmodellben a tumorból származó DNS előrehaladott stádiumban is a teljes szabad DNS mintegy $20 \%$-át teszi ki. A mért értékünk arányban áll a daganat nagyságával is, mivel a 8 . hét végén a tumor mérete az állat testtömegének körülbelül 1/5-ét tette ki. Ez alapján tehát elmondható, hogy a tumor- és az egészséges sejtek tömegarányosan járulnak hozzá a szabad DNS koncentrációjának megemelkedéséhez. Eredményünk összhangban áll Thierry és mtsai megfigyelésével, mely szerint a daganatsejtek által kibocsátott keringő DNS koncentrációja pozitívan korrelál a kialakult tumor méretével [37]. Kutatócsoportjuk nude (meztelen) egér/HT29-es xenograftmodellel dolgozott, majd humán, illetve egérspecifikus KRAS- és PSATl-primerek segítségével kvantitatív PCR-t használva különböztették meg a sejtvonalból és a nude egerekből származó DNS-molekulákat. Leírták, hogy azokban az egerekben, amelyekben a tumor mérete nagyobb volt, szignifikánsan magasabb volt a tumor által kibocsátott humán DNS koncentrációja. A legkisebb daganattal rendelkező egerekben csak az állat saját sejtjei által kibocsátott skDNS-t mértek, a humán sejtvonalból származót nem tudták kimutatni.

A véráramban lévő szabad DNS degradációjának vizsgálata során egy 3000 bp méretü in vitro metilált és nem metilált DNS-szakasz bomlását határoztuk meg 19 individuális real-time PCR-próba használatával. Kísérletünk alapján elmondható, hogy a metilált fragmentumok lassabb degradációval jellemezhetők, mint a nem metiláltak, mivel tovább kimutathatók a vérból. Feltehetőleg az skDNS epigenetikai módosításának következtében a DNáz enzimek kisebb hatásfokkal bontják a metilált DNS-t a módosított térszerkezet következtében, aminek köszönhetően lassabb a degradáció, így nagyobb koncentrációban tovább fennmaradnak a metilált szakaszok. Az egészséges és a tumoros minták összehasonlítása során megállapítottuk, hogy a tumoros állatokban a degradáció lelassul. Ez összefüggésben áll azzal a feltételezé- 
sünkkel, hogy a daganatos betegekben csökken a DNáz-aktivitás, ezáltal tovább kimutatható az injektált DNS-szakasz. A DNáz enzimek mint potenciális antitumor és antimetasztatikus ágensek használata terápiás lehetőségként napjainkban kezd elterjedni. Patutina és mtsai egértumormodellek használatával elemezték a daganatok által kibocsátott szabad DNS és a miRNS-ek kapcsolatát az áttétképződéssel: RNáz-A- és a DNáz-Ikezelés hatását vizsgálták máj- és tüdőmetasztázisokra. Leírták, hogy 0,02-2,3 mg/kg DNáz-I enzim injektálásának hatására szignifikánsan csökkent az áttétek száma a kontrollcsoportokhoz képest, $0,02 \mathrm{mg} / \mathrm{kg}$ mennyiség esetén $9 \pm 3 \mathrm{db} ; 2,3 \mathrm{mg} / \mathrm{kg}$ enzim adásakor pedig $18 \pm$ $4 \mathrm{db}$-ra a kontroll $29 \pm 5 \mathrm{db}$ értékhez képest. A szabad DNS koncentrációjának mérése során az egészséges C57BL/6-os állatokhoz képest $(104 \pm 7 \mathrm{ng} / \mathrm{ml})$ a tumoros egerekben 1,3-szeres emelkedést $(131 \pm 12 \mathrm{ng} /$ $\mathrm{ml}$ ) figyeltek meg, ami a DNáz-I-kezelés után $101 \pm 16$ ng/ml koncentrációra csökkent. Kikalkulálták a Metasztázis Inhibíciós Indexet (MII), melyet a következő képlet alapján számoltak ki: [ metasztázisterület $_{\text {kontroll }}-$ metasztázisterület $\left._{\text {kezelt }}\right) /$ metasztázisterület $\left._{\text {kontroll }} \times 100 \%\right]$. $\mathrm{Az}$ áttétes kontrollállatokban, melyek nem kaptak enzimkezelést, az MII 0\%-ot, a metasztázis hiánya 100\%-ot jelent; 0,02, illetve $2,3 \mathrm{mg} / \mathrm{kg}$ DNáz-I adására az MII értéke 45\%-ra és 36\%-ra ( $\mathrm{p}<0,05)$ emelkedett, ami jelentôs gátlásnak tekinthetô [20].

Trejo-Becerril és mtsai DNáz-I és egy proteázokat tartalmazó mix (tripszin, kimotripszin, papain) injektálása után tanulmányozták, hogy az enzimek mennyire befolyásolják a szabad DNS és a szérumproteinek mennyiségét, valamint megvizsgálták antitumor hatásukat is különböző állatmodellek felhasználásával [38]. Egészséges és tumorral oltott Wistar-patkányok kezelése után megállapították, hogy a szabad DNS szintje abban az esetben csökkent a leginkább, ha a DNáz-I enzimet a proteázokkal együtt használták. Ebből arra következtettek, hogy a szabad DNS nem önállóan, hanem lipoproteinekkel aszszociálva pl. virtoszómákban van jelen a keringésben. Az antitumor hatást BALB/c nude egereken elemezték, melyekre humán vastagbélrák sejtvonalból (SW480) származó sejteket oltottak. Megállapították, hogy a DNáz-I adása önállóan nem, csak a proteázokat tartalmazó mixszel együtt adva váltotta ki antitumor effektusát a kezelést követő 21. naptól. Egy tanulmánynak 2015-ben sikerült bebizonyítania, hogy egészséges és rákos betegekből származó szabad DNS- és kromatinfragmentumok képesek bejutni egér fibroblast sejtekbe és rövidesen a sejtmagba is [39]. Ez volt az első tanulmány, mely leírta, hogy a fragmensek mint mobilis genetikai elemek in vitro és in vivo is képesek integrálódni a genomba. A folyamat azonban DNáz enzim adásának hatására gátlás alá kerül.

\section{Következtetés}

Összefoglalva tehát, a fentebb említett eredményekből következtethetünk arra, hogy a megnövekedett mennyiségű szabad DNS hatással van a tumor fejlődésére, növekedésére, és részt vehet az áttétek képzésében is. A véráramban található DNS-molekulák hordozzák a tumorra jellemző genetikai és epigenetikai mintázatot, valamint a metiláció befolyásolja a DNS lebomlásának sebességét. Továbbá a DNáz enzim adását mint potenciális antitumor faktor hatását érdemes további kísérletekkel vizsgálni.

Anyagi támogatás: A közlemény megírása, illetve a kapcsolódó kutatómunka az OTKA-K111743 és az NVKP16-1-2016-0004 sz. anyagi támogatásokban részesült.

Szerzői munkamegosztás: B. B. K.: A kézirat megírása, kísérletek elvégzése, a szakirodalom kutatása. N. Zs. B.: Kísérletek elvégzése, a kézirat átolvasása. S. S.: Kísérletek megtervezése, a kézirat átolvasása. T. Zs., D. M., I. P., M. B.: A kézirat kritikus átolvasása. A cikk végleges változatát valamennyi szerző elolvasta.

Érdekeltségek: A szerzőknek nincsenek érdekeltségeik.

\section{Irodalom}

[1] Mandel P, Metais P. Les acides nucléiques du plasma sanguin chez l'homme. C R Seances Soc Biol Fil. 1948; 142: 241-243.

[2] Leon SA, Shapiro B, Sklaroff DM, et al. Free DNA in the serum of cancer patients and the effect of therapy. Cancer Res. 1977; 37: 646-650.

[3] Lavon I, Refael M, Zelikovitch B, et al. Serum DNA can define tumor-specific genetic and epigenetic markers in gliomas of various grades. Neuro Oncol. 2010; 12: 173-180.

[4] Pinzani P, Salvianti F, Pazzagli M, et al. Circulating nucleic acids in cancer and pregnancy. Methods 2010; 50: 302-307.

[5] Jung K, Fleishhacker M, Rabien A. Cell-free DNA in the blood as a solid tumor biomarker - a critical appraisal of the literature. Clin Chim Acta 2010; 411: 1611-1624.

[6] Van der Vaart M, Pretorius PJ. Circulating DNA - Its origin and fluctuation. Ann N Y Acad Sci. 2008; 1137: 18-26.

[7] Schwarzenbach H, Hoon DSb, Pantel K. Cell-free nucleic acids as a biomarkers in cancer patients. Nat Rev Cancer 2011; 11 : $426-437$.

[8] Anker P, Stroun M, Maurice PA. Spontaneous release of DNA by human blood lymphocytes as shown in an in vitro system. Cancer Res. 1975; 35: 2375-2382.

[9] Stroun M, Maurice P, Vasioukhin V, et al. The origin and mechanism of circulating DNA. Ann N Y Acad Sci. 2000; 906: 161168.

[10] Wartha F, Beiter K, Normark S, et al. Neutrophil extracellular traps: casting the NET over pathogenesis. Curr Opin Microbiol. 2007; 10: 52-56.

[11] Keshari RS, Jyoti A, Kumar S, et al. Neutrophil extracellular traps contain mitochondrial as well as nuclear DNA and exhibit inflammatory potential. Cytometry A 2012; 81: 238-247. 
[12] Mesa MA, Vasquez G. NETosis. Autoimmune Dis. 2013; 2013: 651497.

[13] Peters DL, Pretorius PJ. Origin, translocation and destination of extracellular occurring DNA - a new paradigm in genetic behaviour. Clin Chim Acta 2011; 412: 806-811.

[14] Mouliere F, Thierry AR. The importance of examining the proportion of circulating DNA originating from tumor, microenvironment and normal cells in colorectal cancer patients. Expert Opin Biol Ther. 2012; 12 (Suppl 1): 209-215.

[15] D'Souza-Schorey C, Clancy JW. Tumor-derived microvesicles: shedding light on novel microenvironment modulators and prospective cancer biomarkers. Genes Dev. 2012; 26: 1287-1299.

[16] Valcz G, Galamb O, Krenács T, et al. Exosomes in colorectal carcinoma formation: ALIX under the magnifying glass. Mod Pathol. 2016; 29: 928-938.

[17] Spisák S, Solymosi N, Ittzés P, et al. Complete genes may pass from food to human blood. PLoS ONE 2013; 8: e69805.

[18] Kowarsky M, Camunas-Soler J, Kertesz M, et al. Numerous uncharacterized and highly divergent microbes which colonize humans are revealed by circulating cell-free DNA. Proc Natl Acad Sci USA 2017; 114: 9623-9628.

[19] Tamkovich SN, Cherepanova AV, Kolesnikova EV, et al. Circulating DNA and DNase activity in human blood. Ann N Y Acad Sci. 2006; 1075: 191-196.

[20] Patutina O, Mironova N, Ryabchikova E, et al. Inhibition of metastasis development by daily administration of ultralow doses of RNase A and DNase I. Biochimie 2011; 93: 689-696.

[21] Anker P, Lyautey J, Lefort F, et al. Transformation of NIH/3T3 cells and SW 480 cells displaying K-ras mutation. C R Acad Sci III 1994; 317: 869-874.

[22] García-Olmo D, García-Olmo DC. Functionality of circulating DNA: the hypothesis of genometastasis. Ann N Y Acad Sci. 2001; 945: 265-275.

[23] Nagy B, Csanádi Z, Póka R. The importance of "free" nucleic acids in the non-invasive diagnostics. [A „szabad” nukleinsavak jelentősége a noninvazív diagnosztikában.] Orv Hetil. 2016; 157: 1900-1909. [Hungarian]

[24] Ziegler A, Zangemeister-Wittke U, Stahel RA. Circulating DNA: a new diagnostic gold mine? Cancer Treat Rev. 2002; 28: 255271.

[25] Fearon ER, Vogelstein B. A genetic model for colorectal tumorigenesis. Cell 1990; 61: 759-767.

[26] Tóth K, Barták BK, Tulassay Z, et al. Circulating cell-free nucleic acids as biomarkers in colorectal cancer screening and diagnosis. Expert Rev Mol Diagn. 2016; 16: 239-252.

[27] Wang JY, Hsieh JS, Chang MY, et al. Molecular detection of APC, K-ras, and p53 mutations in the serum of colorectal cancer patients as circulating biomarkers. World J Surg. 2004; 28: 721726.
[28] Edwards JR, Yarychkivska O, Boulard M, et al. DNA methyla tion and DNA methyltransferases. Epigenetics Chromatin 2017; 10: 23 .

[29] Joó JG, Karabélyos C, Héjja H, et al. Epigenetic mechanisms in physiologic and pathologic pregnancies. [Epigenetikai mechanizmusok élettani és kóros terhességben.] Orv Hetil. 2014; 155: 566-574. [Hungarian]

[30] Molnár B, Tóth K, Barták BK, et al. Plasma methylated septin 9: a colorectal cancer screening marker. Expert Rev Mol Diagn. 2015; 15: 171-184.

[31] Potter NT, Hurban P, White MN, et al. Validation of a real-time PCR-based qualitative assay for the detection of methylated SEPT9 DNA in human plasma. Clin Chem. 2014; 60: 11831191 .

[32] Johnson DA, Barclay RL, Mergener K, et al. Plasma Septin9 versus fecal immunochemical testing for colorectal cancer screening: a prospective multicenter study. PLoS ONE 2014; 9: e98238.

[33] Nian J, Sun X, Ming S, et al. Diagnostic accuracy of methylated SEPT9 for blood-based colorectal cancer detection: a systematic review and meta-analysis. Clin Transl Gastroenterol. 2017; 8: e216.

[34] Tóth K, Galamb O, Spisák S, et al. Free circulating DNA based colorectal cancer screening from peripheral blood: the possibility of the methylated septin 9 gene marker. [Szabad DNS-alapú vastagbéldaganat-szúrés perifériás vérből: a metilált szeptin-9 génmarker lehetôségei.] Orv Hetil. 2009; 150: 969-977. [Hungarian]

[35] Barták BK, Kalmár A, Péterfia B, et al. Colorectal adenoma and cancer detection based on altered methylation pattern of SFRPI, SFRP2, SDC2, and PRIMA1 in plasma samples. Epigenetics 2017; 12: 751-763.

[36] Tusnady GE, Simon I, Varadi A, et al. BiSearch: primer-design and search tool for PCR on bisulfite-treated genomes. Nucleic Acids Res. 2005; 33: e9.

[37] Thierry AR, Mouliere F, Gongora C. Origin and quantification of circulating DNA in mice with human colorectal cancer xenografts. Nucleic Acids Res. 2010; 38: 6159-6175.

[38] Trejo-Becerril C, Pérez-Cardenas E, Gutiérrez-Díaz B, et al. Antitumor effects of systemic DNAse I and proteases in an in vivo model. Integr Cancer Ther. 2016; 15: NP35-NP43.

[39] Mittra I, Khare NK, Raghuram GV, et al. Circulating nucleic acids damage DNA of healthy cells by integrating into their genomes. J Biosci. 2015; 40: 91-111.

(Barták Barbara Kinga,

Budapest, Szentkirályi u. 46., 1088 e-mail: bartak.barbara.kinga@gmail.com)

\section{„Az egzakt tudomány a megingathatatlan szilárd bázisa az orvos hivatásának. Rossz orvos az, aki egyszersmind nem tudós és nem kutató." (Leyden)}

